\title{
Optical and Electrochemical Properties of Non-Peripheral Thioaryl-Substituted Subphthalocyanine as Precursors for Dye-Sensitizer to Develop Photovoltaic Cells
}

\author{
Keiichi Sakamoto ${ }^{1,2 *}$, Satoru Yoshino', Makoto Takemoto², Kazuhiro Sugaya ${ }^{2}$, \\ Hitomi Kubo², Tomoe Komoriya1, Shinnosuke Kamei1, Shigeki Furukawa1,2 \\ ${ }^{1}$ Department of Sustainable Engineering, College of Industrial Technology, Nihon University, Tokyo, Japan \\ ${ }^{2}$ Academic Major of Applied Molecular Chemistry, Graduate School of Industrial Technology, Nihon University, \\ Tokyo, Japan \\ Email: ${ }^{*}$ sakamoto.keiichi@nihon-u.ac.jp
}

Received 6 September 2014; revised 21 October 2014; accepted 6 November 2014

Copyright (C) 2014 by authors and Scientific Research Publishing Inc.

This work is licensed under the Creative Commons Attribution International License (CC BY). http://creativecommons.org/licenses/by/4.0/

c) (i) Open Access

\section{Abstract}

Phthalocyanines-related compounds, subphthalocyanines, are the homologues consisting of three isoindole units with boron as the center. The absorption maximum of subphthalocyanines, called the $Q$ band, appears around $560-630 \mathrm{~nm}$, which is shifted by approximately $100 \mathrm{~nm}$ to shorter wavelengths compared to phthalocyanines. Subphthalocyanines are used as precursors to prepare unsymmetric phthalocyanines for ring enlargement reaction. In this decade, phthalocyanines are used for dye-sensitized solar cells (DSSCs), which require strong absorption of far-red light between 700 and $850 \mathrm{~nm}$ because of their highly efficiency. Non-peripheral thioaryl-substituted phthalocyanines have been synthesized. They show near-infrared absorption around $780-870 \mathrm{~nm}$ and have excellent electron transfer properties. However, their lack of affinity to basal plats inhibits their use as DSSC photosensitizer. Therefore, to synthesize unsymmetrical non-peripheral thioaryl-substituted phthalocyanines possessing good affinity to basal plates, the authors prepared subphthalocyanines having thioaryl substituents as precursors. Spectroscopic properties and electron transfer abilities to synthesize non-peripheral thioaryl-substituted subphthalocyanines were estimated using cyclic voltammetry. The $Q$ band of non-peripheral thioaryl-substituted subphthalocyanines shows around $650 \mathrm{~nm}$ shifted to longer wavelength by $86 \mathrm{~nm}$ in comparison to subphthalocyanine. The compounds show many reduction potentials. They are acceptable electrons in the subphthalocyanine ring, meaning that the compounds have good electron transfer

\footnotetext{
*Corresponding author.
}

How to cite this paper: Sakamoto, K., Yoshino, S., Takemoto, M., Sugaya, K., Kubo, H., Komoriya, T., Kamei, S. and Furukawa, S. (2014) Optical and Electrochemical Properties of Non-Peripheral Thioaryl-Substituted Subphthalocyanine as Precursors for Dye-Sensitizer to Develop Photovoltaic Cells. American Journal of Analytical Chemistry, 5, 1037-1045. 


\title{
properties.
}

\section{Keywords}

\author{
Thioaryl Substituents, Phthalocyanines, Subphthalocyanine, Cyclic Voltammetry, Precursor for \\ Dye-Sensitizer
}

\section{Introduction}

Phthalocyanines have been used as important green to blue dyes and pigments. At the present time, phthalocyanines are known for their use as important functional colorants for various applications such as catalysts, electron charge carriers, and photosensitizers [1]-[4]. The photosensitization property of phthalocyanines has attracted attention for use in photovoltaic cells, especially dye-sensitized solar cells (DSSCs), which are regarded as next-generation solar cells [5]-[10]. So far, ruthenium complexes e.g. black dye and N3 dye have been used as photosensitizers in DSSC technology. Nevertheless, ruthenium complexes have an important shortcoming. They lack absorption in the near-infrared region.

In order to use DSSCs, phthalocyanines as photosensitizers are required to have a strong absorption of visible light in the far-red or near-infrared region. Phthalocyanines have high capability of conversion of solar energy to electricity [11]-[13]. In fact, phthalocyanines have been applied as photosensitizers on titania $\left(\mathrm{TiO}_{2}\right)$-based solar cells [14]-[17]. As photosensitizers, phthalocyanines harvest solar photons, which promote photoinduced electron into the conduction band of $\mathrm{TiO}_{2}$.

The strongest absorption of phthalocyanines in the visible region called the $\mathrm{Q}$ band can be moved by red shift through introduction of an electron-donating substituent at a peripheral (2, 3, 9, 10, 16, 17, 23, 24) position [18]. Then, the non-peripheral $(1,4,8,11,15,18,22,25)$ substituted phthalocyanines can show a bathochromic effect in comparison with the peripheral position [4] [19].

Non-peripheral substituted octakis(hexylsulfanyl)phthalocyanines were moved in the Q band from $780 \mathrm{~nm}$ [20]. Alkyl substituents linked through heteroatoms have the important effect of moving the $Q$ band to the nearinfrared region [20]. Then, the Q band of nonplanar non-peripheral substituted octakis( $p$-methoxyphenyl)phthalocyanines was shifted beyond $800 \mathrm{~nm}$ [21] [22]. Although most metal phthalocyanines have a planar structure, the bathochromic effect of the Q band observed for the octakis( $p$-methoxyphenyl)phthalocyanines arises from ligand deformation [21] [22]. Moreover, the authors have reported that the Q bands of non-peripheral substituted octakis(thioaryl)phthalocyanines appeared at around $860 \mathrm{~nm}$ [5].

The non-peripheral substituted octakis(thioaryl)phthalocyanines are assumed to have low affinity to basal plates such as $\mathrm{TiO}_{2}$. Low affinity to titania is caused by thioaryl substituents. It is well known that titania shows good affinity to carboxyl groups. Accordingly, 3:1 type unsymmetric phthalocyanines containing six thioaryl groups at non-peripheral positions have molecular-designed possessing anchoring functional groups, such as carboxy groups, at peripheral positions, which show affinity to $\mathrm{TiO}_{2}$. In general, unsymmetric phthalocyanines are known to be prepared with stoichometric mixture of raw materials [4], or to be synthesized from corresponding subphthalocyanine and phthalic derivatives. In the former case synthesized unsymmetric phthalocyanines were formed alongside the mixture of condensation products and their regioisomers. Then it is very difficult for the separation and identification of their mixture. In later method, corresponding subphthalocyanines act as precursors for phthalocyanine synthesis of ring-enlargement technique. Subphthalocyanines are homologues that have the molecular structure of phthalocyanine. They consist of three isoindole units with boron as the center of the molecule. Synthesized unsymmetric phthalocyanines from subphthalocyanines as precursors are not containing mixtures of condensation products and their regioisomers. The later methods have a merit in analytical chemistry.

In this study, non-peripheral substituted hexakis(thioaryl)subphthalocyanines are synthesized as precursors of 3:1 type unsymmetric hexakis(thioaryl)phthalocyanines possessing anchoring functional groups. The non-peripheral substituted hexakis(thioaryl)subphthalocyanines are estimated to have their own basic properties of spectroscopic tendency in comparison with the corresponding octakis(thioaryl)phthalocyanines and electron transfer ability using cyclic voltammetry (CV). 


\section{Experimental}

\subsection{Equipment}

Infrared (IR) spectra were recorded on a Shimadzu IR-8400A spectrometer and a Perkin-Elmer Spectrum 65 FT-IR spectrometer. Ultraviolet-visible (UV-Vis) spectra were measured on a Shimadzu UV-2400PC spectrometer, while fluorescence spectra were measured on a Nihon Bunko JASCO FP-6000 fluorescence spectrometer. Each sample was prepared in chloroform at a concentration of $5.0 \times 10^{-5} \mathrm{~mol} \cdot \mathrm{dm}^{-3}$. The proton magnetic resonance $\left({ }^{1} \mathrm{H}\right.$ NMR) spectra were measured at $400 \mathrm{MHz}$ on a Bruker Advance $400 \mathrm{~S}$ and $500 \mathrm{MHz}$ on a Bruker AdvanceIII 500 in dimethylsulfoxide (DMSO)- $d_{6}$ using tetramethylsilane as the internal standard. Elemental analysis was carried out using a Perkin-Elmer 2400CHN instrument. Mass (MS) spectra were taken with a Nihon Denshi Joel JMS-AX500 mass spectrometer. CVs were recorded on an ALS electrochemical analyzer 600D at room temperature in $o$-dichlorobenzene or chloroform containing $0.1 \mathrm{~mol} \cdot \mathrm{dm}^{-3}$ tetrabutylammonium perchlorate (TBAP). CVs were recorded by scanning the potential at a rate of $50 \mathrm{~m} \cdot \mathrm{Vs}^{-1}$. The working and counter electrodes were platinum wires, and the reference electrode was a silver (Ag)/silver chloride (AgCl) electrode. The area of the working electrode was $2.0 \times 10^{-2} \mathrm{~cm}^{2}$.

\subsection{Materials}

All chemicals were purchased from Aldrich or Tokyo Chemical Industry. They were used as received without further purification. For chromatographic separation, silica gel was used (60, particle size $0.063-0.200 \mathrm{~nm}$, 7734-grade; Merck).

\subsection{Synthesis}

Target compounds, hexakis(thioaryl)subphthalocyanines (3), were synthesized in three steps via intermediates, phthalonitrile-3,6-ditriflate (1) and 3,6-bis(thiophenyl)phthalonitriles (2).

\subsubsection{Phthalonitrile-3,6-ditriflate (1)}

A compound 2,3-dicyanohydroquinone ( $4.80 \mathrm{~g}, 30 \mathrm{mmol})$ in dichloromethane $\left(100 \mathrm{~cm}^{3}\right)$ and pyridine (py) (5.93 $\mathrm{g}, 75 \mathrm{mmol})$ was treated with trifluoromethanesulfonic anhydride $(21.16 \mathrm{~g}, 75 \mathrm{mmol})$ under argon at $-78^{\circ} \mathrm{C}$. After the reaction, the mixture was allowed to warm slowly to room temperature; stirring was continued for $24 \mathrm{~h}$. The mixture was poured into water $\left(600 \mathrm{~cm}^{3}\right)$. Then the organic layer was extracted using dichloromethane $(5 \times$ $100 \mathrm{~cm}^{3}$ ). The extract was washed in turn with water, $2 \%$-hydrochloric acid, water, brine and water, and dried on magnesium sulfate $\left(\mathrm{MgSO}_{4}\right)$. The filtrate and the solvent evaporated. The crude product was recrystallized from dichloromethane to afford $\mathbf{1}$ (6.35 g, 50\%) as colorless needles. Found: C, 28.32\%; H, 0.48\%; N, 6.59\%. Calcd. for $\mathrm{C}_{10} \mathrm{H}_{2} \mathrm{~F}_{6} \mathrm{~N}_{2} \mathrm{~S}_{2} \mathrm{O}_{6}$ : C, 28.31\%; H, 0.48\%; F, 26.87\%; N, 6.60\%; O, 22.63\%; S, 15.12\%. IR (KBr): $\mathrm{cm}^{-1} 3115$ $\left(v_{\mathrm{C}-\mathrm{H}}\right), 2550\left(v_{\mathrm{C}-\mathrm{N}}\right), 1601\left(v_{\mathrm{C}-\mathrm{C}}\right), 1472\left(v_{\mathrm{C}-\mathrm{C}}\right), 1439\left(v_{\mathrm{C}-\mathrm{C}}\right), 1134\left(v_{\mathrm{S}=\mathrm{O}}\right) .{ }^{1} \mathrm{H}$ NMR (400 MHz, DMSO-d $\left.d_{6}\right): \delta$, ppm $8.44(\mathrm{~s}, 2 \mathrm{H})$.

\subsubsection{3,6-Bis(thiophenyl)phthalonitriles (2)}

In a mixture of $1(0.85 \mathrm{~g}, 2 \mathrm{mmol})$, potassium carbonate $(1.16 \mathrm{~g})$ and dimethyl sulfoxide (DMSO) $\left(15 \mathrm{~cm}^{3}\right)$, thiophenols (4 mmol) for instance $p$-toluenethiol, 4-methoxybenzenethiol and tert-butylthiophenol was added; the mixture was reacted at room temperature for $24 \mathrm{~h}$ in nitrogen atmosphere. The reaction products were poured into water $\left(300 \mathrm{~cm}^{3}\right)$, and the organic layer extracted using dichloromethane $\left(5 \times 100 \mathrm{~cm}^{3}\right)$, and dried on $\mathrm{MgSO}_{4}$. The filtrate and the solvent evaporated. The crude product was washed with methanol $\left(3 \times 50 \mathrm{~cm}^{3}\right)$ and recrystallized from toluene to afford $\mathbf{2}$ as a yellow solid. A compound 3,6-bis(thiophenylmethyl)phthalonitrile (2a) (0.43 g, 56\%) Found: C, 70.90\%; H, 4.30\%; N, 7.50\%. Calcd. for $\mathrm{C}_{22} \mathrm{H}_{16} \mathrm{~N}_{2} \mathrm{~S}_{2}$ : C, 70.93\%; H, 4.33\%; N, 7.52\%; S, 17.22. IR (KBr): $\mathrm{cm}^{-1} 3050\left(v_{\mathrm{C}-\mathrm{H}}\right), 2970\left(v_{\mathrm{C}-\mathrm{H}}\right), 2218\left(v_{\mathrm{C}-\mathrm{N}}\right), 1600\left(v_{\mathrm{C}-\mathrm{C}}\right), 1535\left(v_{\mathrm{C}-\mathrm{C}}\right), 1490\left(v_{\mathrm{C}-\mathrm{C}}\right), 1435\left(v_{\mathrm{C}-\mathrm{C}}\right)$, 1210, $809\left(v_{\mathrm{C}-\mathrm{H}}\right) .{ }^{1} \mathrm{H}$ NMR (400 MHz, DMSO-d 6 ): $\delta$, ppm $7.54(\mathrm{~d}, 4 \mathrm{H}), 7.46(\mathrm{~d}, 4 \mathrm{H}), 7.35(\mathrm{~s}, 2 \mathrm{H}), 2.66$ (tt, $\left.6 \mathrm{H}\right)$; 3,6-bis(thiophenylmethoxy)phthalonitrile (2b) (0.61 g, 75\%) Found: C, 65.30\%; H, 4.00\%; N, 6.93\%. Calcd. for $\mathrm{C}_{22} \mathrm{H}_{16} \mathrm{~N}_{2} \mathrm{~S}_{2} \mathrm{O}_{2}$ : C, 65.32\%; H, 3.99\%; N, 6.93\%; S, 15.82\%; O, 7.91\%. IR (KBr): $\mathrm{cm}^{-1} 3050\left(v_{\mathrm{C}-\mathrm{H}}\right), 2970\left(v_{\mathrm{C}-\mathrm{H}}\right)$, $2216\left(v_{\mathrm{C}-\mathrm{N}}\right), 1600\left(v_{\mathrm{C}-\mathrm{C}}\right), 1540\left(v_{\mathrm{C}-\mathrm{C}}\right), 1487\left(v_{\mathrm{C}-\mathrm{C}}\right), 1430\left(v_{\mathrm{C}-\mathrm{C}}\right), 1210,810\left(v_{\mathrm{C}-\mathrm{H}}\right) \cdot{ }^{1} \mathrm{H}$ NMR (400 MHz, DMSO-d $\left.d_{6}\right)$ : $\delta$, ppm $7.49(\mathrm{~d}, 4 \mathrm{H}), 7.06(\mathrm{~d}, 4 \mathrm{H}), 7.04(\mathrm{~s}, 2 \mathrm{H}), 3.79(\mathrm{~s}, 6 \mathrm{H})$; 3,6-bis(thiophenyltert-butyl)phthalonitrile (2c) (0.38 g, 42\%) Found: C, 73.65\%; H, 6.18\%; N, 6.11\%. Calcd. for $\mathrm{C}_{28} \mathrm{H}_{28} \mathrm{~N}_{2} \mathrm{~S}_{2}$ : C, 73.64\%; $\mathrm{H}, 6.18 \%$; N, 6.13\%; 
S, 14.04\%. IR (KBr): cm ${ }^{-1} 3040\left(v_{\mathrm{C}-\mathrm{H}}\right), 2960\left(v_{\mathrm{C}-\mathrm{H}}\right), 2210\left(v_{\mathrm{C}-\mathrm{N}}\right), 1600\left(v_{\mathrm{C}-\mathrm{C}}\right), 1500\left(v_{\mathrm{C}-\mathrm{C}}\right), 1460\left(v_{\mathrm{C}-\mathrm{C}}\right), 1210,808$ $\left(v_{\mathrm{C}-\mathrm{H}}\right) .{ }^{1} \mathrm{H}$ NMR $\left(400 \mathrm{MHz}, \mathrm{DMSO}-d_{6}\right): \delta$, ppm 7.50 (d, 4H), 7.46 (d, 4H), 7.26 (s, 2H), $1.28(\mathrm{~s}, 18 \mathrm{H})$.

\subsubsection{Non-Peripheral Thioaryl-Substituted Subphthalocyanines (3)}

A mixture of 2 (10.0 mmol) and boron trichloride $\left(6 \mathrm{~cm}^{3}, 1 \mathrm{~mol} \cdot \mathrm{dm}^{-3}\right.$ in $p$-xylene) in 1-chloronaphthalene (18 g) was refluxed at $150^{\circ} \mathrm{C}$ for 30 min under argon atmosphere. The products were dissolved in toluene. Into the toluene solution, hexane was added to precipitate non-peripheral thioaryl-substituted subphthalocyanines. The non-peripheral thioaryl-substituted subphthalocyanines were column-chromatographed on silica gel with chloroform as eluent. Hexakis(thiophenylmethyl)subphthalocyanine (3a) (2.00 g, 17\%) Found: C, 67.68\%; H, 3.96\%; N, 6.81\%. Calcd. for $\mathrm{C}_{66} \mathrm{H}_{48} \mathrm{~N}_{6} \mathrm{~S}_{6} \mathrm{BCl}$ : C, 68.11\%; H, 4.16\%; N, 7.22\%. IR (KBr): $\mathrm{cm}^{-1} 3020\left(v_{\mathrm{C}-\mathrm{H}}\right), 2920$ $\left(v_{\mathrm{C}-\mathrm{H}}\right), 2864\left(v_{\mathrm{C}-\mathrm{H}}\right), 1586\left(v_{\mathrm{C}-\mathrm{C}}\right), 1546\left(v_{\mathrm{C}-\mathrm{C}}\right), 1490\left(v_{\mathrm{C}-\mathrm{C}}\right), 1449\left(v_{\mathrm{C}-\mathrm{C}}\right), 1415,1380,807\left(v_{\mathrm{C}-\mathrm{H}}\right) .{ }^{1} \mathrm{H}$ NMR $(500 \mathrm{MHz}$, DMSO- $\left.d_{6}\right): \delta$, ppm $7.62(\mathrm{~d}, 12 \mathrm{H}), 7.29(\mathrm{~d}, 12 \mathrm{H}), 6.94(\mathrm{~d}, 6 \mathrm{H}), 2.33(\mathrm{~s}, 18 \mathrm{H})$. MS (FAB) $\mathrm{m} / \mathrm{z}$ found 1163, calcd. 1163.78. Hexakis(thiophenylmethoxy)subphthalocyanine (3b) (0.85 g, 7\%) Found: C, 62.91\%; H, 3.78\%; N, 6.40\%. Calcd. for $\mathrm{C}_{66} \mathrm{H}_{48} \mathrm{~N}_{6} \mathrm{~S}_{6} \mathrm{O}_{6} \mathrm{BCl}$ : C, 62.92\%; H, 3.84\%; N, 6.67\%. IR (KBr): $\mathrm{cm}^{-1} 3056\left(v_{\mathrm{C}-\mathrm{H}}\right), 2933\left(v_{\mathrm{C}-\mathrm{H}}\right)$, $2840\left(v_{\mathrm{C}-\mathrm{H}}\right), 1591\left(v_{\mathrm{C}-\mathrm{C}}\right), 1566\left(v_{\mathrm{C}-\mathrm{C}}\right), 1504\left(v_{\mathrm{C}-\mathrm{C}}\right), 1489\left(v_{\mathrm{C}-\mathrm{C}}\right), 968,786,758\left(v_{\mathrm{C}-\mathrm{H}}\right) .{ }^{1} \mathrm{H}$ NMR (500 MHz, DMSO- $d_{6}$ ): $\delta$, ppm 7.68 (d, 12H), 7.00 (d, 12H), 6.87 (d, 6H), 3.82 (s, 18H). MS (FAB) $\mathrm{m} / \mathrm{z}$ found 1259, calcd. 1259.28. Hexakis(thiophenyltert-butyl)subphthalocyanine (3c) (0.41 g, 7\%) Found: C, 71.27\%; H, 5.63\%; N, 5.97\%. Calcd. for $\mathrm{C}_{84} \mathrm{H}_{84} \mathrm{~N}_{6} \mathrm{~S}_{6} \mathrm{BCl}$ : C, 71.24\%; H, 5.98\%; N, 5.93\%. IR (KBr): $\mathrm{cm}^{-1} 3057\left(v_{\mathrm{C}-\mathrm{H}}\right), 2954\left(v_{\mathrm{C}-\mathrm{H}}\right)$, $1592\left(v_{\mathrm{C}-\mathrm{H}}\right), 1504\left(v_{\mathrm{C}-\mathrm{C}}\right), 1458\left(v_{\mathrm{C}-\mathrm{C}}\right), 835,820\left(v_{\mathrm{C}-\mathrm{H}}\right) .{ }^{1} \mathrm{H}$ NMR $\left(500 \mathrm{MHz}, \mathrm{DMSO}-d_{6}\right): \delta$, ppm $7.70(\mathrm{~d}, 12 \mathrm{H})$, 7.48 (d, 12H), 6.95 (d, 6H), 1.35 (d, 54H). MS (FAB) $\mathrm{m} / \mathrm{z}$ found 1415, calcd. 1416.26.

\section{Results and Discussion}

\subsection{Synthesis of Non-Peripheral Thioaryl-Substituted Subphthalocyanines}

The synthetic route to the target hexakis(thioaryl)subphthalocyanines (3) were shown in Scheme 1. Target compounds $\mathbf{3}$ were synthesized in three steps via intermediates, $\mathbf{1}$ and $\mathbf{2}$. Intermediate $\mathbf{1}$ was synthesized from 2,3-dicyanohydroquinone and trifluoromethanesulfonic anhydride [4] [5]. Intermediates 2 were synthesized from 1, and $p$-toluenethiol, 4-methoxybenzenethiol and tert-butylthiophenol, respectively to obtained 3,6-bis (thiophenylmethyl)phthalonitrile (2a), bis(thiophenylmethoxy)phthalonitrile (2b), and 3,6-bis(thiophenyltertbutyl) phthalonitrile (2c). Intermediates 1 and 2 were analyzed using IR and ${ }^{1} \mathrm{H}$ NMR spectroscopy, and elemental analysis. Their analytical data showed good agreement with proposed structure.

The obtained target compounds non-peripheral thioaryl substituted subphthalocyanines (3) such as hexakis (thiophenylmethyl)subphthalocyanine (3a), hexakis(thiophenylmethoxy)subphthalocyanine (3b) and hexakis (thiophenyltert-butyl)subphthalocyanine (3c) were synthesized from corresponding intermediates $\mathbf{2 a}$, 2b and $\mathbf{2 c}$, respectively, and boron trichloride in 1-chlonaphthalene under argon atmosphere. The products of $\mathbf{3}$ were purified using column chromatography on silica gel with chloroform as eluent. The target compounds 3 were analyzed using IR, ${ }^{1} \mathrm{H}$ NMR and MS spectroscopy, and elemental analysis. The analytical data showed good agreement with the proposed structure.

In general, subphthalocyanines show pinkish red color and have a shuttle-coke form molecular structure.

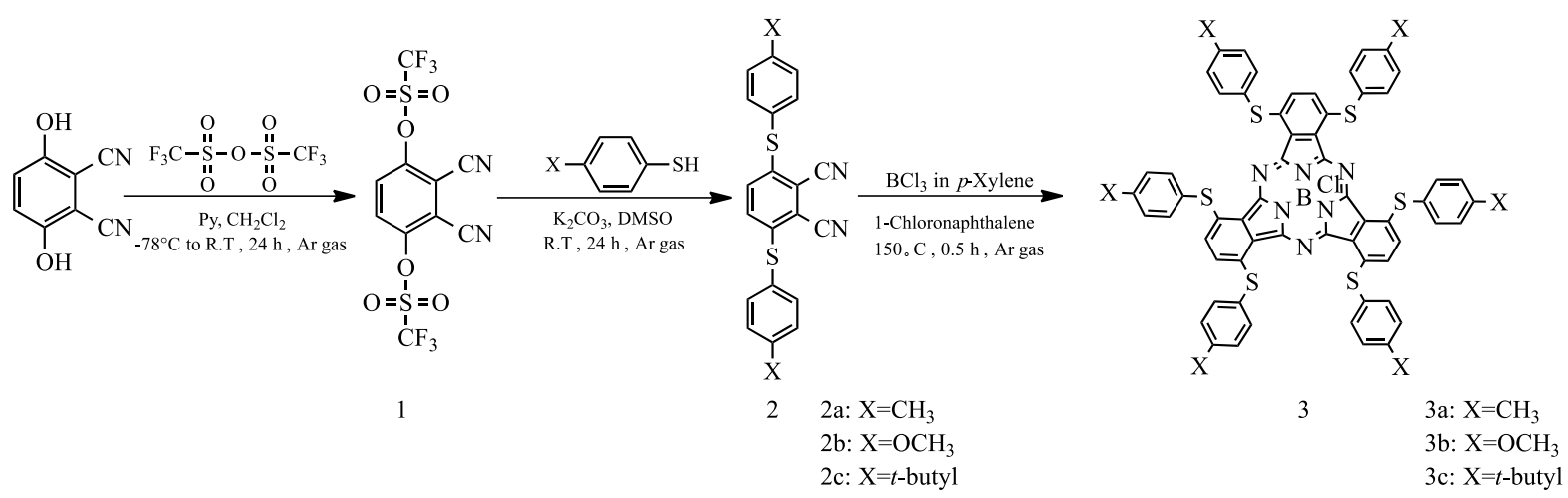


Comparison with thioalkyl-substituted fluorosubphthalocyanines [23] and subphthalocyanines, compounds 3 appear at longer absorption maxima. The phenomena are asuumed that the 3:1 type unsymmetric phthalocyanines prepared from precursors are expected to have longer wavelength maxima at near-infrared region.

\subsection{Optical Properties of Non-Peripheral Thioaryl-Substituted Subphthalocyanines}

Strong absorption of phthalocyanines in the visible region between 650 and $690 \mathrm{~nm}$, called the Q band, can be attributed to the allowed highest occupied molecular orbital (HOMO) - lowest unoccupied molecular orbital (LUMO) $\pi-\pi^{*}$ transition and in UV between 329 and $370 \mathrm{~nm}$, called the Soret band. Absorption maxima of subphthalocyanine and thioalkyl-substituted fluorosubphthalocyanines appeared around 560 to $630 \mathrm{~nm}$ with increasing their molecular weight [23]. The strongest absorption peak assignee are the $\mathrm{Q}$ band, which is attributed $\pi-\pi^{*}$ transition in the same manner as phthalocyanines. The Q band absorption peaks of subphthalocyanines were shifted by $100 \mathrm{~nm}$ to a hypsochromic effect in comparison with corresponding phthalocyanines. The shorter wavelength shift depends upon the change in electron-distribution in the size of their $\pi$ conjugated macro ring, so-called porphyrazines ring.

The UV-Vis spectra of compounds 3 and subphthalocyanine were shown in Figure 1. The Q band of compounds 3 shows around $650 \mathrm{~nm}$. As mentioned above, the $Q$ band of subphthalocyanine appeared around 560 $\mathrm{nm}$. The Q band of compounds 3 moved to longer wavelength by $86 \mathrm{~nm}$ in comparison to subphthalocyanine.

It is well known that subphthalocyanine have corn shape molecular arising from three isoindole units whereas phthalocyanines possess planer structure as the result of their porphyrazines rings consisting of four isoindole units. Since the compounds 3 have remarkably bulky substituents, the molecular distortion is increased. Then, the electron distribution is changed in subphthalocyanine ring. The steric hindrance arises from substituted thioaryl groups, which appear to be as significant [22]. The authors think that the bathochromic effects of Q bands in compounds 3 arise from the steric hindrance of molecular structure similar to phthalocyanines having bulky substituents [5] [21] [22]. The difference of Q band absorption in 3 is however low between substituents, methyl, methoxy, and tert-butyl groups. The chromopher of subphthalocanines as same as phthalocyanines are $\pi$-conjugated macro rings, hence substituents only slightly affect the movement to bathochromic effect. The Q band data of $\mathbf{3}$ are presented in Table 1.

Fluorescence and excitation spectra of $\mathbf{3}$ are shown in Figure 2. Fluorescence spectra of $\mathbf{3}$ appeared around $681 \mathrm{~nm}$. Of cause, the excitation spectra have almost same of absorption spectra. The fluorescence spectra of 3 appeared as a mirror image of their excitation spectra. The difference of maximum value of $\mathbf{3}$ between fluorescence and excitation spectra showed approximately $30 \mathrm{~nm}$.

Fluorescence is reflected as aromatic and/or conjugation double-bonded with a high degree of resonance stability. The same as the fluorescence maxima of $\mathbf{3}$ signifies dependence on the $\pi$ electron environment. The difference in maxima of spectra is called a Stokes shift. In the general case of phthalocyanines, including subphthalocyanines, the value of the Stokes shift is relatively small in a few nanometers. The phenomena mean that phthalocyanines form rigid molecules between their ground and excited electronic states. In the case of $\mathbf{3}$, the molecules transform their structures between electron transitions because the constitutions of $\mathbf{3}$ exhibit flexibility as a result of their remarkable bulky substituents. Since compounds $\mathbf{3}$ possess bulky thioaryl substitutions at

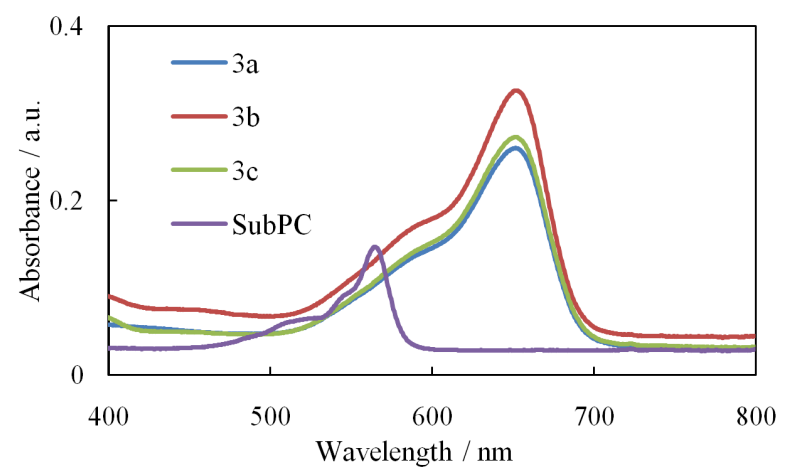

Figure 1. UV-Vis spectra of non-periperal thioaryl-substituted subphthalocyanines (3) and subphthalocyanine. 
Table 1. The Q band absorption data of target compounds 3a, $\mathbf{3 b}$ and $\mathbf{3 c}$, and subphthalocyanine.

\begin{tabular}{ccccc}
\hline & 3a & 3b & 3c & SubPC \\
\hline$\lambda_{\max } / \mathrm{nm}$ & 651.5 & 651.5 & 651.0 & 564.5 \\
$\log \varepsilon$ & 3.48 & 3.61 & 3.33 & 4.23 \\
\hline
\end{tabular}
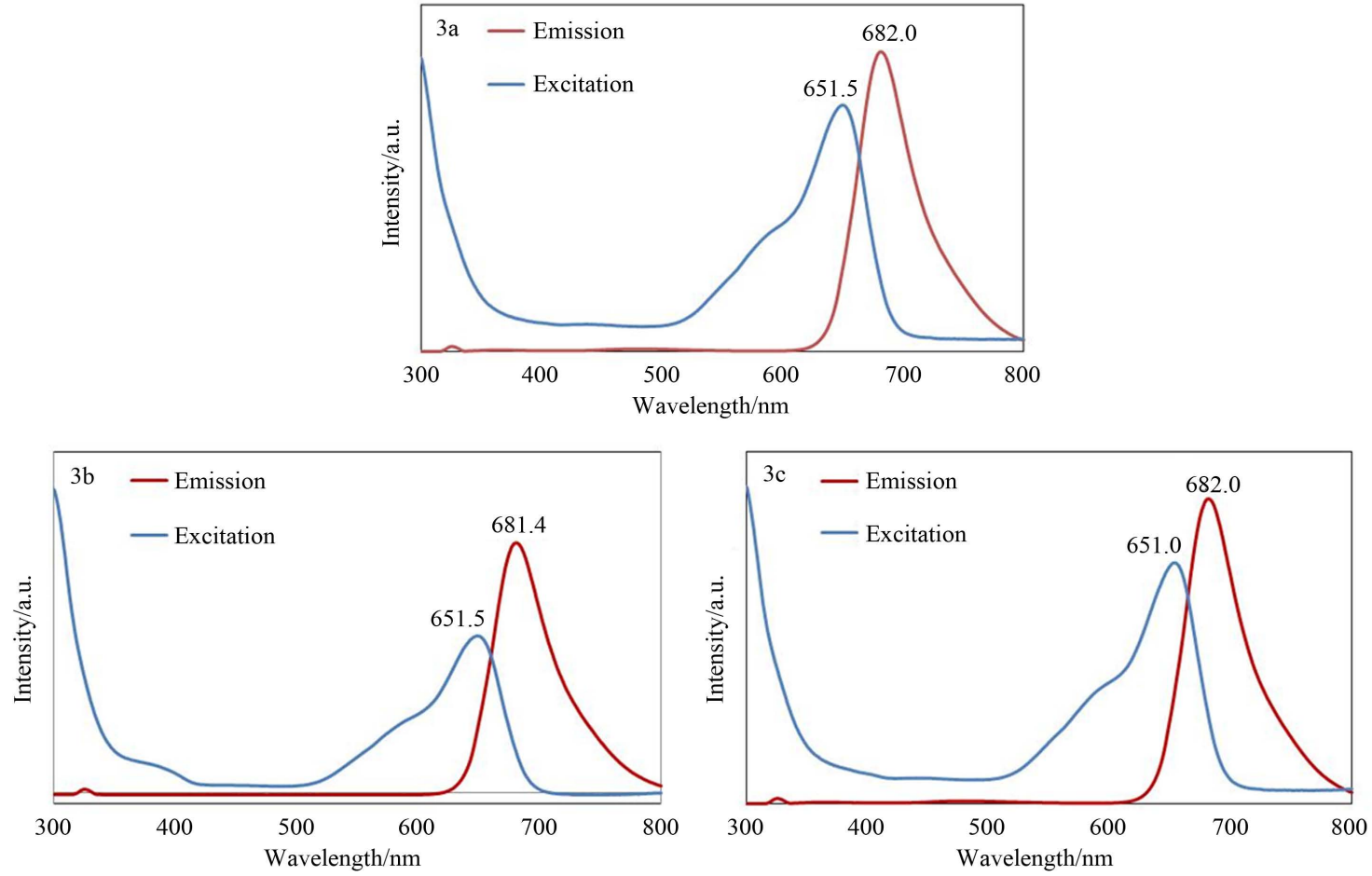

Figure 2. Fluorescence and excitation spectra of compounds $\mathbf{3 a} \mathbf{3} \mathbf{3 b}$ and $\mathbf{3 c}$.

non-peripheral positions, the stability of molecules was different from each conformation between grand and excited state. The compounds 3 have distorted molecular structure. Similar phenomena were observed bulky substituted phthalocyanines [5] [21] [22].

In order to make unsymmetric 3:1 type phthalocyanines were reacted to obtain metal-free corresponding phthalocyanines.

Hexakis(thiophenylmethyl)phthalocyanine appeared at $773 \mathrm{~nm}$ in Q band, shifted by $122 \mathrm{~nm}$ to longer wavelength than the corresponding compound 3a. The Q bands of non-peripheral substituted octakis(thioaryl)phthalocyanines appeared at around $800 \mathrm{~nm}$, especially metal-free octakis(thioaryl)phthalocyanines showed longer wavelength than corresponding metal phthalocyanines [5]. The Q band of synthesized hexakis(thiophenylmethyl)phthalocyanine is showed shorter wavelength by $42 \mathrm{~nm}$ in comparison with non-peripheral substituted octakis(thiophenylmethyl)phthalocyanine, which appeared at $815 \mathrm{~nm}$ [5]. Singh and his co-workers reported that that unsymmetric phthalocyanines prepared with stoichiometric mixture of raw materials appeared at $750 \mathrm{~nm}$ [24], which means that the Q band depends upon the electron distribution caused by number of substitution. The ring enlargement technique is suitable for the synthesis of unsymmetric 3:1 type phthalocyanine.

\subsection{Electrochemical Properties on Non-Peripheral Thioaryl-Substituted Subphthalocyanines}

CVs were carried out with an ALS electrochemical analyzer 600D at room temperature in $o$-dichlorobenzene and/or chloroform containing $0.1 \mathrm{~mol} \cdot \mathrm{dm}^{-3}$ TBAP. Important parameters of CVs are the reduction and oxidation potentials for irreversible peaks, and the mid-point potential for reversible couple $\left(E_{\mathrm{mid}}\right)$. The shapes of CVs are 
present as upward cathodic (reduction) and downword anodic (oxidation) peaks. Electrochemical properties were estimated from CV analysis.

A typical CV of 3a is shown in Figure 3. The CVs of $\mathbf{3}$ show similar shapes except for subphthalocyanine. The shapes of 3a showed upward cathodic (reduction) peaks and downward (oxidation) peaks. These pair of peaks appeared around $-1.74,-1.56,-1.28,-1.14,+0.62$ and $0.90 \mathrm{~V}$ vs. Ag/AgCl. Differences in CVs between solvents are caused by gaps of their dipole moments. Oxidation and reduction potentials were summarized in Table 2.

In general, metal phthalocyanines having transition metal behave as electrochemically irreversible, and exhibit reduction and oxidation properties resulting from interaction between the phthalocyanine ring and their central metal. The oxidation potential is about $1.0 \mathrm{~V}$ vs. standard hydrogen electrode (SHE). The reduction potential occurs between -0.3 and $-0.8 \mathrm{~V}$ vs. SHE. Electrons are added either to the molecular orbital of the phthalocyanine ring or the central metal, depending on the reduction-oxidation potential for reduction process. For subphthalocyanines, the authors have reported that an irreversible reduction potential appeared around $-0.3 \mathrm{~V}$ vs. $\mathrm{Ag} / \mathrm{AgCl}$ [23]. The irreversible peaks of subphthalocyanines are attributed to the deduction of the subphthalocyanine ring. The reduction and oxidation potentials of subphthalocyanines result from their substituents.

Table 2. Reduction and oxidation potential of compounds 3a and 3c in o-dichlorobenzen or chloroform with tetrabutylammonium perchlorate.

\begin{tabular}{|c|c|c|c|c|c|c|c|}
\hline \multirow[b]{3}{*}{ 3a } & \multicolumn{7}{|c|}{ Potential/V vs. Ag/AgCl o-Dichlorobenzene Solvent } \\
\hline & \multicolumn{5}{|c|}{ Reduction } & \multicolumn{2}{|c|}{ Oxidation } \\
\hline & -1.74 & -1.56 & -1.28 & -1.14 & $-0.92^{*}$ & 0.62 & 0.90 \\
\hline 3c & & -1.69 & -1.15 & $-0.90^{*}$ & & 0.62 & 0.88 \\
\hline \multirow[t]{3}{*}{ SubPC } & & \multicolumn{4}{|c|}{-1.31} & \multicolumn{2}{|l|}{0.75} \\
\hline & \multicolumn{7}{|c|}{ Potential/V vs. Ag/AgCl Chloroform Solvent } \\
\hline & \multicolumn{5}{|c|}{ Reduction } & \multicolumn{2}{|c|}{ Oxidation } \\
\hline 3a & & & -1.81 & $-1.43^{*}$ & & $0.80^{*}$ & \\
\hline $3 c$ & & & -1.81 & & & $0.74^{*}$ & \\
\hline SubPC & & & $-1.52^{*}$ & $-1.20^{*}$ & & $0.81^{*}$ & \\
\hline
\end{tabular}

Potentials of reversible wave are midpoint of anodic and cathodicpraks for each couple $\mathrm{E}_{1 / 2}$

*Irreversible peak.

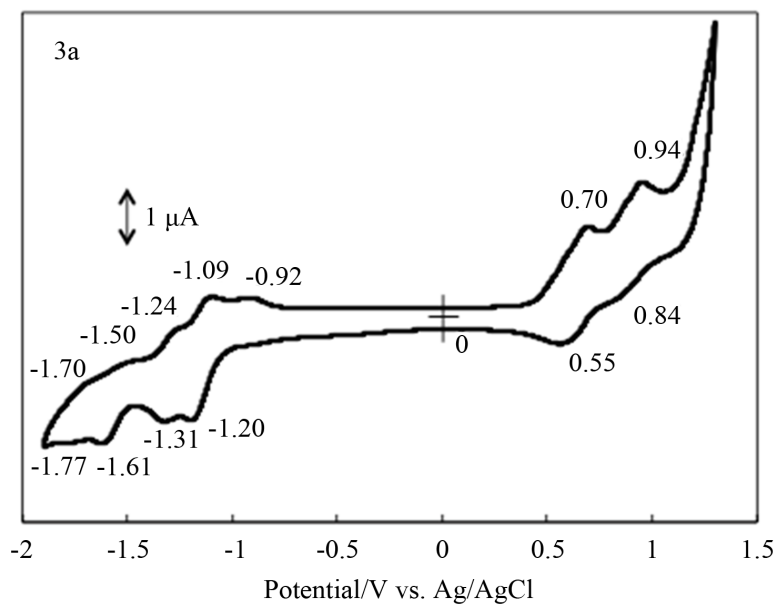

Figure 3. A typical cyclic voltammogram of compound 3a. 
CVs of compounds $\mathbf{3}$ differ in terms of shape from subphthalocyanine, 3a have many reduction and oxidation peaks. These phenomena mean that the substituents variedly act in accordance with their electro-donating property for methyl, methoxy and tert-butyl, although they do not demonstrate the effect as chromophores. The substituents of compounds $\mathbf{3}$ are affected more by subphthalocyanines than porphyrazines ring before reported corresponding octakis(thioaryl)phthalocyanines [7]. Compounds 3 show many reduction potentials and are acceptable electrons in the subphthalocyanine ring compare with corresponding octakis(thioaryl)phthalocyanines.

\section{Conclusions}

Hexakis(thioaryl)subphthalocyanines 3a-3c were synthesized in three steps in order to prepare the precursor of 3:1 type unsymmetric hexakis(thioaryl)phthalocyanines.

The Q band of compounds 3 shows around $650 \mathrm{~nm}$ shift to longer wavelength by $86 \mathrm{~nm}$ in comparison to subphthalocyanine.

Compounds 3 show many reduction potentials. They are acceptable electrons in the subphthalocyanine ring, meaning that the compounds $\mathbf{3}$ have good electron transfer properties.

\section{References}

[1] Campidell, S., Ballesteros, B., Filoramo, A., Diaz, D., de la Torre, G., Torres, T., Rahman, G.M.A., Aminur, E.C., Kissling, D., Werner, F., Sgobba, V., Guldi, D.M., Cioffi, C., Prato, M. and Bourgoin, J.-P. (2008) Facile Decoration of Functionalized Single-Wall Carbon Nanotubes with Phthalocyanines via "Clic Chemistry". Journal of the American Chemical Society, 130, 11503-11509. http://dx.doi.org/10.1021/ja8033262

[2] Pinzon, J.R., Plnska-Brzezinska, M.E., Cadona, C.M., Athans, A.J., Gayathri, S.S., Guldi, D.M., Herranz, M.A., Martin, N. and Torres, T. (2008) Sc3N@C80-Ferrocen Electron-Doner/Acceptor Conjugates as Promising Materials for Photovoltaic Applications. Angewandte Chemie International Edition, 47, 4173-4176. http://dx.doi.org/10.1002/anie.200800473

[3] Ichikawa, M., Kobayashi, K., Koyama, T. and Taniguchi, Y. (2007) Intense and Efficient Ultraviolet Electroluminescence from Organic Light-Emitting Devices with Fluorinated Copper Phthalocyanines as Hole Injection Layer. Thin Solid Films, 515, 3932-3935. http://dx.doi.org/10.1016/j.tsf.2006.11.012

[4] Sakamoto, K., Yoshino, S., Takemoto, M. and Furuya, N. (2013) Syntheses of Near Infrared Absorbed Phthalocyanines to Utilized Photosensitizers. Journal of Porphyrins and Phthalocyanines, 17, 605-627. http://dx.doi.org/10.1142/S1088424613500326

[5] Sakamoto, K., Ohno-Okumura, E., Kato, T. and Soga, H. (2010) Synthesis of Near-Infrared Absorbed Metal Phthalocyanine with S-Aryl Groups at Non-Peripheral Positions. Journal of Porphyrins and Phthalocyanines, 14, 47-54. http://dx.doi.org/10.1142/S1088424610001726

[6] Sakamoto, K., Furuya, N. and Soga, H. (2012) Synthesis Novel Phthalocyanines for Solar Cells and Their Spectroscopic and Electrochemical Properties. Journal of the Japan Society of Colour Material, 85, 2-8. http://dx.doi.org/10.4011/shikizai.85.2

[7] Sakamoto, K., Furuya, N., Soga, H. and Yoshino, S. (2013) Cyclic Voltammetry of Non-Peripheral Thioaryl Substituted Phthalocyanines. Dyes and Pigments, 96, 430-434. http://dx.doi.org/10.1016/j.dyepig.2012.08.025

[8] Hagfeldt, A. and Gratel, M. (200) Molecular Photovoltaics. Accounts of Chemical Research, 33, 269-277. http://dx.doi.org/10.1021/ar980112j

[9] Nazeeruddin, M.K., Kay, A., Rodicio, I., Humphry-Baker, R., Muller, E., Kiska, P., Valachopoulos, V. and Gratzel, M. (1993) Conversion of Light to Electricity by Cis-X2bis(2,2'-bipyridil-4,4'-dicarboxylate)ruthenium (II) Charge-Transfer Sensitizers (X = Cl-, Br-, CN- and SCN-) on Nanocrysatlline Titanium Dioxide Electrodes. Journal of the American Chemical Society, 115, 6382-6390. http://dx.doi.org/10.1021/ja00067a063

[10] Yoshida, T., Zhang, J., Komatsu, D., Sawatani, S., Minoura, H., Pauport, T., Lincot, D., Oekermann, T., Schlettwein, D., Tada, H., Wohrle, D., Funabiki, K., Matsui, M., Miura, H. and Yanagi, H. (2009) Electrodeposition of Inorgnic/ Organic Hibrid Thin Films. Advanced Functional Materials, 19, 17-43. http://dx.doi.org/10.1002/adfm.200700188

[11] Ragoussi, M.E., Cid, J.J., Yum, J.H., de la Torre, G., Censo, D.D., Gratzel, M., Nazeeruddin, M.K. and Torres, T. (2012) Carboxyethynyl Anchoring Ligands: A Means to Improving the Efficiency of Phthalocyanine-Sensitized Solar Cells. Angewandte Chemie International Edition, 51, 4375-4378.

[12] Nomura, K., Loewenstein, T., Michaelis, E., Wogrle, D., Yoshida, T., Minoura, H. and Schlettwein, D. (2006) Photoelecrochemical Characterization and Optimization of Electrodeposited ZnO Thin Films Sensitized by Porphyrins and Phthalocyanines. Physical Chemistry Chemical Physics, 8, 3867-3875. http://dx.doi.org/10.1039/b604352f

[13] Idowu, M., Loewenstein, T., Hastall, A., Nyokong, T. and Schlettwein, D. (2010) Photoelectrochemical Characteriza- 
tion of Electrodeposited ZnO Thin Films Sensitized by Octacarboxymetallophthalocyanine Derivatives. Journal of Porphyrins and Phthalocyanines, 14, 142-149. http://dx.doi.org/10.1142/S1088424610001854

[14] Cid, J.J., Yum, J.H., Jang, S.R., Nazeeruddin, M.K., Martinez-Ferrero, E., Palomares, E., Ko, J., Graetzel, M. and Torres, T. (2007) Molecular Co-Sensitization for Efficient Panchromatic Dye-Sensitized Solar Cells. Angewandte Chemie International Edition, 46, 8358-8362.

[15] Eu, S., Katoh, T., Umeyama, T., Matano, Y. and Imahori, H. (2008) Synthesis of Sterically Hindered Phthalocyanines and Their Applications to Dye-Sensitized Solar Cells. Dalton Transactions, 2008, 5476-5484. http://dx.doi.org/10.1039/b803272f

[16] Giribabu, L., Vijay-Kumar, C.H., Yella-Reddy, P., Yum, J.H., Gratzel, M. and Nazeeruddin, M.K. (2009) Unsymmetrical Extended $\pi$-Conjugated Zinc Phthalocyanine for Sensitization of Nanocrystalline $\mathrm{TiO}_{2}$ Films. Journal of Chemical Sciences, 121, 75-82. http://dx.doi.org/10.1007/s12039-009-0008-9

[17] Macor, L., Fungo, F., Temesti, T., Durantini, E.N., Otero, L., Barea, E.M., Fabregat-Santiago, F. and Bisquert, J. (2009) Near-IR Sensitization of Wide Band Gap Oxide Semiconductor by Axially Anchored Si-Naphthalocyanines. Energy \& Environmental Science, 2, 529-534.

[18] De la Torre, G., Vazques, P., Agullo-Leopez, F. and Torres, T. (2004) Roll of Structural Factors in the Nonlinear Optical Properties of Phthlocyanines and Related Compounds. Chemical Reviews, 104, 3723-3750. http://dx.doi.org/10.1021/cr030206t

[19] Cook, M.J., Chambrier, I., Cracknell, S.J., Mayes, D.A. and Russel, D.A. (1995) Octa-Alkyl Zinc Phthalocyanines: Potential Photosensitizers for Use Photodynamic Therapy of Cancer. Photochemistry and Photobiology, 62, 542-545. http://dx.doi.org/10.1111/j.1751-1097.1995.tb02381.x

[20] Cook, M.J., Dunn, A.J., Howe, S.D., Thomson, A.J. and Harrison, K.J. (1988) Octa-Alkoxy Phthalocyanine and Naphthalocyanine Derivatives: Dyes with Q-band Absorption in the Far Red or Near Infrared. Journal of the Chemical Society, Perkin Transactions 1, 1988, 2453-2458. http://dx.doi.org/10.1039/p19880002453

[21] Fukuda, T., Ishiguro, T. and Kobayashi, N. (2005) Non-Planer Phthalocyanines with Q-Bands beyond $800 \mathrm{~nm}$. Tetrahedron Letters, 46, 2907-2909.

[22] Kobayashi, N., Fukuda, T., Ueno, K. and Ogino, H. (2001) Extremely Non-Planer Phthalocyanines with Saddle or Helical Conformations: Synthesis and Structural Characterizations. Journal of the American Chemical Society, 123, 10740-10741. http://dx.doi.org/10.1021/ja0113753

[23] Ohno-Okumura, E., Sakamoto, K., Kato, T., Hatano, T., Fukui, K., Karatsu, T., Kitamura, A. and Urano, T. (2002) Synthesis of Subphthalocyanine Derivatives and Their Characterization. Dyes and Pigments, 53, 57-65. http://dx.doi.org/10.1016/S0143-7208(01)00102-4

[24] Singh, V.K., Salvatori, P., Amet, A., Agrawal, S., De Angelis, F., Nazeeruddin, M.K., Krishna, N.V. and Giribabu, L. (2014) Near-Infrared Absorbing Unsymmetrical Zn(II) Phthalocynine for Dye-Sensitized Cells. Inorganica Chimica Acta, 407, 289-296. http://dx.doi.org/10.1016/j.ica.2013.07.052 
Scientific Research Publishing (SCIRP) is one of the largest Open Access journal publishers. It is currently publishing more than 200 open access, online, peer-reviewed journals covering a wide range of academic disciplines. SCIRP serves the worldwide academic communities and contributes to the progress and application of science with its publication.

Other selected journals from SCIRP are listed as below. Submit your manuscript to us via either submit@scirp.org or Online Submission Portal.
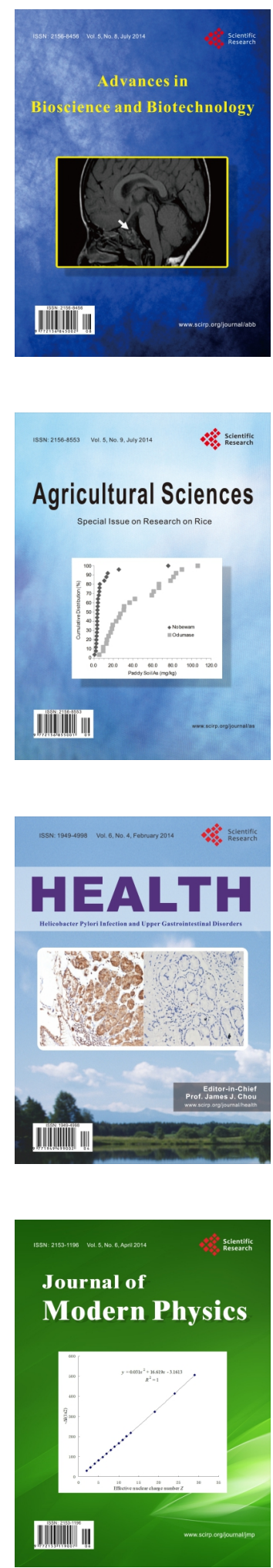
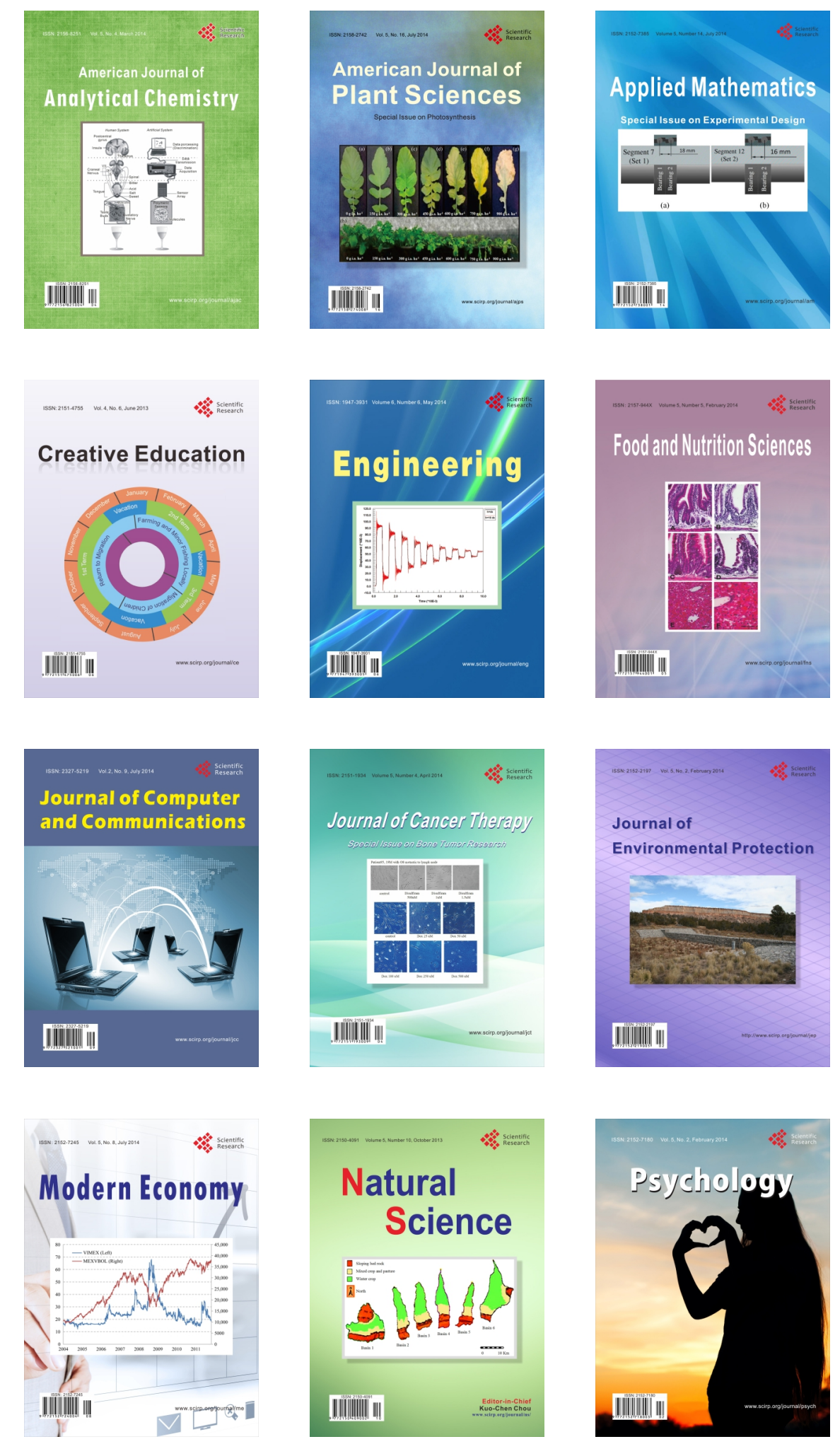